Annals of Warsaw University of Life Sciences - SGGW

Land Reclamation No 41 (2), 2009: 131-141

(Ann. Warsaw Univ. of Life Sciences - SGGW, Land Reclam. 41 (2), 2009)

\title{
Preliminary criteria for ecological status assessment index for dam reservoirs on the basis of the ichthyofauna assemblages
}

\author{
WIESŁAW WIŚNIEWOLSKI, PAWEŁ PRUS
}

The Stanislaw Sakowicz Inland Fisheries Institute, River Fisheries Department

\begin{abstract}
Preliminary criteria for ecological status assessment index for dam reservoirs on the basis of the ichthyofauna assemblages. Basing on geographical, physical and hydrological criteria, 24 types of dam reservoirs can be distinguished in Poland. The system of ecological potential assessment is based on the index of biotic integrity (IBI), taking into account its modifications for Polish rivers. An example of a table with assessment criteria values is given for large, lowland, lotic reservoirs. In order to use the proposed assessment system it is necessary to elaborate such tables for all 24 types of reservoirs and than to test it on a sample of reservoirs of each type. It is worth of notice, that to obtain appropriate data on ichthyofauna of dam reservoirs for assessment of their ecological potential, it is necessary to use combined methods of data collection (electrofishing, commercial and experimental net catches) in a planned monitoring system.
\end{abstract}

Key words: WFD, dam reservoirs, ecological potential, assessment methods, ichthyofauna.

\section{INTRODUCTION}

Directive 2000/60/WE of the European Parliament and the Council of 23 October 2000 establishing a framework for Community action in the field of water policy, called the Water Framework Directive (WFD) requires the Member States of the European Union to bring into force several obligations and recommendations aimed at classifying water environment, establishing principles and criteria of ecological assessment and, in short-term perspective, reaching "good environmental status". The principal difference in the approach towards the assessment of environmental status and monitoring principles of surface waters presented in WFD refers to the key role of biological indicators in determining the environmental status, including different hydrobionts assemblages such as phytoplankton, macrophytes, macrozoobenthos and ichthyofauna. Most of the so-far used monitoring systems, especially in the countries located in Central Europe, were based on traditional, chemical indicators and saprobity indexes that used lists of indicator organisms from some phytoplankton and zoobenthos groups. Biological components of water status assessment were used in these systems only in a limited scope, mostly as easily measured parameters such as: biological oxygen demand $\left(\mathrm{BOD}_{5}\right)$, chlorophyll $a$ content or Coli titer. The new approach towards assessment of water ecological status enclosed in WFD requires not only a change and widening of the scope of database systems in environmental monitoring, but above all an elaboration of reliable methods aimed at assessing the ecological status of waters on the basis of particular biological components.

Studies aimed at determining the method of biological assessment of 
water ecosystem status have been carried out in various members states of the European Union since a few years and have reached different stages: from ready systems, requiring further testing and local modifications, such as the case of the European Fish Index (EFI) (Schmutz et al. 2007) and the newly established EFI + index (Improvement... 2009), or the German index based on macrozoobenthos, elaborated in the framework of the AQUEM programmes for rivers, to very preliminary stages of work, such as, for example, the Polish proposal to establish an ecological assessment index for the status of lakes based on ichthyofauna assemblages, prepared in The Stanislaw Sakowicz Inland Fisheries Institute.

It should be noted that until now the attention was given to methods that focused at evaluating the natural environment such as rivers, lakes or coastal and transitional waters, whereas not much attention was given to artificial and heavily modified water bodies, notwithstanding clear provisions of the WFD, that put an obligation on the member states to achieve good environmental status and good chemical status of these waters until 2015 (Article 4, item 1, letter a, paragraph 3) and to implement monitoring systems that include the ecological potential assessment for these waters until the end of 2006 (Article 8). It should be underlined that the maximum ecological potential for particular types of artificial and heavily modified bodies of water, constituting an equivalent of reference conditions for rivers and lakes, can only be established on the basis of experts' assessments that take into account the existing knowledge as well as analogies to similar natural environments, due to the lack of unmodified environments of this type.

In view of the above, one of the most urgent actions to be undertaken in the implementation of WFD should be aimed at elaborating systems of ecological potential assessment of artificial and heavily modified water bodies, with the use of the already existing systems or those under preparation as well as at elaborating a monitoring programme for those modified environments.

Dam reservoirs are among the most frequent types of heavily modified waters, with substantial ecological importance. In Poland, the number of reservoirs with a surface of more than 20 ha can be estimated at approximately 130 ( $6 \%$ of the lakes of the same surface), whereas the number of reservoirs with a surface of more than 1000 ha reaches 14 , that is over $40 \%$ of the number of lakes of the same surface (Starmach et al. 1976, Mastyński 1985). This proves a substantial share of dam reservoirs in surface waters in Poland, whereas their role is particularly important in those areas where lakes are scares.

Ichthyofauna assemblages constitute a valuable element of biological assessment of the ecological status and ecological potential of waters, in particular due to a long life cycle of the studied organisms and their location at higher levels of the trophic pyramid of ecosystems (consumers of the second and higher levels). A limited number of fish species that exist in Poland (83 taxons - Brylińska 2000) as well as very easy species determination also by non-ichthyologists play also a role. 
However, some restrictions derive from the methodology of reliable sample collection from the environment as well as assessment of the fish density and biomass.

This study puts forward preliminary criteria for the typology of dam reservoirs as well as the system of their assessment on the basis of ichthyofauna, with the use of indicators elaborated for rivers, in particular the index of biotic integrity (IBI) (Karr 1981; McDonough, Hickman 1999), taking into account the modifications done for rivers in Poland (Buras et al. 2004, Szlakowski et al. 2004).

\section{METHODS AND RESULTS}

\section{Typology of dam reservoirs}

On the basis of geographical criteria (altitude above sea level), physical criteria (surface and mean depth) as well as hydrological regime (retention time), it is proposed to distinguish 24 types of dam reservoirs (Tab. 1).

The division of dam reservoirs into size classes corresponds to Mastyński (1985) and altitude classes (m.a.s.l.) are in conformity with the provisions of Water Framework Directive. The criteria of mean depth (shallow and deep reservoirs)

TABLE 1. Dam-reservoir types distinguished on the basis of geographical, physical and hydrological criteria

\begin{tabular}{|c|c|c|c|c|c|}
\hline Group of reservoirs & $\begin{array}{l}\text { Type } \\
\text { No }\end{array}$ & $\begin{array}{c}\text { Surface area } \\
{[\text { ha] }}\end{array}$ & $\begin{array}{l}\text { Altitude } \\
\text { [m.a.s.1.] }\end{array}$ & $\begin{array}{l}\text { Mean depth } \\
{[\mathrm{m}]}\end{array}$ & $\begin{array}{l}\text { Retention time } \\
\text { [days] }\end{array}$ \\
\hline \multirow[t]{4}{*}{ Large lowland } & 1 & $>1000$ & $<200$ & $\geq 5$ & $\geq 30$ \\
\hline & 2 & $>1000$ & $<200$ & $\geq 5$ & $<30$ \\
\hline & 3 & $>1000$ & $<200$ & $<5$ & $\geq 30$ \\
\hline & 4 & $>1000$ & $<200$ & $<5$ & $<30$ \\
\hline \multirow{4}{*}{$\begin{array}{l}\text { Large highland } \\
\text { and mountain }\end{array}$} & 5 & $>1000$ & $\geq 200$ & $\geq 5$ & $\geq 30$ \\
\hline & 6 & $>1000$ & $\geq 200$ & $\geq 5$ & $<30$ \\
\hline & 7 & $>1000$ & $\geq 200$ & $<5$ & $\geq 30$ \\
\hline & 8 & $>1000$ & $\geq 200$ & $<5$ & $<30$ \\
\hline \multirow{4}{*}{$\begin{array}{l}\text { Medium size } \\
\text { lowland }\end{array}$} & 9 & $301-1000$ & $<200$ & $\geq 5$ & $\geq 30$ \\
\hline & 10 & $301-1000$ & $<200$ & $\geq 5$ & $<30$ \\
\hline & 11 & $301-1000$ & $<200$ & $<5$ & $\geq 30$ \\
\hline & 12 & $301-1000$ & $<200$ & $<5$ & $<30$ \\
\hline \multirow{4}{*}{$\begin{array}{l}\text { Medium size } \\
\text { highland and } \\
\text { mountain }\end{array}$} & 13 & $301-1000$ & $\geq 200$ & $\geq 5$ & $\geq 30$ \\
\hline & 14 & $301-1000$ & $\geq 200$ & $\geq 5$ & $<30$ \\
\hline & 15 & $301-1000$ & $\geq 200$ & $<5$ & $\geq 30$ \\
\hline & 16 & $301-1000$ & $\geq 200$ & $<5$ & $<30$ \\
\hline \multirow[t]{4}{*}{ Small lowland } & 17 & $20-300$ & $<200$ & $\geq 5$ & $\geq 30$ \\
\hline & 18 & $20-300$ & $<200$ & $\geq 5$ & $<30$ \\
\hline & 19 & $20-300$ & $<200$ & $<5$ & $\geq 30$ \\
\hline & 20 & $20-300$ & $<200$ & $<5$ & $<30$ \\
\hline \multirow{4}{*}{$\begin{array}{l}\text { Small highland } \\
\text { and mountain }\end{array}$} & 21 & $20-300$ & $\geq 200$ & $\geq 5$ & $\geq 30$ \\
\hline & 22 & $20-300$ & $\geq 200$ & $\geq 5$ & $<30$ \\
\hline & 23 & $20-300$ & $\geq 200$ & $<5$ & $\geq 30$ \\
\hline & 24 & $20-300$ & $\geq 200$ & $<5$ & $<30$ \\
\hline
\end{tabular}


and retention time in lotic (reolimnic) and limnic reservoirs (Starmach et al. 1976) have also been applied. The proposed division is purely theoretical and requires verification in comparison with detailed data on the reservoirs in Poland. Some of the proposed types may not exist in Poland (for example type 6 and 14), but nevertheless can exist in other EU member states.

The proposed typology excludes reservoirs below 20 ha in surface due to the necessity to limit the number of reservoirs under assessment. The smallest reservoirs, often just consisting of a damming up above the weir and not larger than the river bed, can be treated as its heavily modified parts, whereas small pond-like reservoirs are not included in the assessment system, similarly to the smallest lakes and ponds due to their excessive number.

\section{Elaboration of criteria for ecological} assessment of the status of dam reservoirs

The principles for establishing criteria and system for assessment originate from the study by McDonough and Hickman (1999), including modifications done for rivers in Poland (Buras et al. 2004, Szlakowski et al. 2004). The assessment system is based on the scheme designed for the biotic integrity index IBI (Karr 1981), which includes only the parameters of ichthyofauna assemblages. The reason for such approach is artificial origin and disturbance of natural parameters of retention in the studied water environments, that practically prevents the use of their morphologic and hydrologic parameters as criteria for ecological potential assessment.

In addition, as mentioned earlier, the maximum ecological potential for particular types of dam-reservoirs can be determined only on the basis of experts' assessments, due to the lack of possibility to determine the reference conditions for environments created through human activity.

The principle behind the proposed index is based on allocating a given number of points to the values attributed to particular assessment criteria (Tab. 2) (1, 3 or 5 points - respectively for low, medium andhigh assessmentofecological potential). The points are aggregated and each sum (from 12 to 60 ) is classified according to a five grade ecological potential classification presented in Annex V of WFD: high (53-60 points), good (45-52), moderate (36-44), poor (24-35) and bad (12-23). This method permits to assess the ecological potential of the studied reservoir according to a five grade scale.

The range of values of particular parameters, corresponding to a given number of points (1, 3 or 5 points) should be elaborated separately for each of the 24 types of reservoirs, by taking into account its specific nature and expertise on a given type of water environment. For example, a number of fish species corresponding to a high grade in case of a small, shallow reservoir will be much lower than for a large, deep and lotic. The assessment criteria and principles of allocating a given sum of points one of the 5 grades of ecological potential should be uniform for all reservoir types, thus allowing a direct comparison of the obtained results. 
TABLE 2. Criteria chosen for assessment of ecological potential of dam-reservoirs

\begin{tabular}{|c|c|c|}
\hline No & Criteria & $\begin{array}{c}\text { Impact on } \\
\text { the assess- } \\
\text { ment }\end{array}$ \\
\hline 1 & Total number of species & + \\
\hline 2 & Number of intolerant species & + \\
\hline 3 & Number of piscivore species & + \\
\hline 4 & Number of invertivore species* & + \\
\hline 5 & Number of lithophilic and phytophylic spawning species & + \\
\hline 6 & Percent biomass of piscivore fish & + \\
\hline 7 & Percent biomass of invertivores* & + \\
\hline 8 & Per cent biomass of tolerant species (bream, white bream, roach, silver carp) & - \\
\hline 9 & Domination (\% biomass of dominant species) & - \\
\hline 10 & $\begin{array}{l}\text { Sub-dominants - number of species with the share }>10 \% \text { in the biomass, ex- } \\
\text { cluding the dominant species }\end{array}$ & + \\
\hline 11 & Stocking with piscivore species $\left(\mathrm{kg}^{\cdot} \cdot \mathrm{ha}^{-1} \cdot \mathrm{year}^{-1}\right)^{* *}$ & + \\
\hline 12 & Exploitation of piscivore species $\left(\mathrm{kg} \cdot \mathrm{ha}^{-1} \cdot \mathrm{year}^{-1}\right)$ & - \\
\hline
\end{tabular}

The "+" means that higher value of a criterion gives higher index, "--" - that higher value of a criterion gives lower index value.

* excluding the white bream,

** amount of stocking recalculated for most commonly used stocking material (young of the year).

The assessment criteria proposed in Table 2 are composed to permit to most precise characteristics of species abundance, diversity of trophic groups, proportions of biomass of particular species groups, structure of domination in an ichthyofauna assemblage as well as the direct impact of human activity on fish assemblages in assessed reservoirs. Below, particular assessment criteria are explained in detail, highlighting their index value to assess the ecological potential.

1. Total number of fish species - larger number of species indicates a better ecological status of the ecosystem. Alien species (introduced on purpose, introduced or brought from other river systems through artificial connections between the systems) are taken into account only if they created self-sustaining populations.

2. Number of intolerant species (rheophilic species with greater oxygen requirements) - species such as barbel, nase, chub, asp, ide, common dace; in mountain reservoirs also: lake trout and brown trout, whitefish and Danube salmon - are sensitive to various aspects of environmental degradation. Due to usually scarce occurrence of these species and the possible underestimation of their biomass the criterion present/none is used instead of percentage share in the fish biomass.

3. Number of piscivore species - species such as pike, pike perch, catfish, asp, lake trout, Danube salmon, eel and perch are important indicators 
of environmental status and also a factor regulating the abundance of other species, in particular including tolerant species, often overpopulated in reservoirs.

4. Number of invertivores - species such as tench, perch, ruff, common dace, bleak, vimba, gudgeon, barbel are highly specialised in terms of food requirements, often composed of invertebrates and small fish, therefore their presence indicates a good environmental status of water ecosystems. The presence of white bream, also belonging to tolerant species is not taken into account.

5. Number of lithophilic and phytophylic spawning species - species such as asp, barbel, chub, sneep or ruff, ide, common dace, perch, pike perch spawn on hard surface (mineral or plant), which is less and less accessible in reservoirs along with increasing deposition of residues and silting up of the bottom, which is one of the factors causing degradation of water environments.

6. Percent biomass of piscivore fish - piscivore species are an important element of the ichthyofauna and their high biomass proves a good environmental status of a reservoir, even if it results mostly from stockings and not natural spawning of these species. For this reason this criterion has been included, contrary to the opinion expressed by McDonough and Hickman (1999), that it should be excluded due to intensive stocking (thus considering the abundance of these species as unnatural).

7. Percent biomass of invertivores-these species (tench, perch, ruff, common dace, bleak, vimba, gudgeon, barbel) are highly specialised in terms of food requirements and thus their high biomass constitutes an indicator of a good environmental status of water ecosystems. The presence of white bream, also belonging to tolerant species is not taken into account.

8. Per cent biomass of tolerant species - these species (bream, white bream, roach, silver carp) tolerate well low concentration of oxygen in water and an increase of the biogen content and at the same time feed on diversified food (sometimes also plants and detritus). Due to this, they reach very high biomasses in heavily modified and degraded water environments, where other species with more specific food and habitat requirements cannot exist. Therefore, their high biomass is considered to be an indicator of environmental degradation in dam reservoirs. The number of these fish species has not been considered as an indicator since they are common in almost every dam reservoir.

9. Domination (\% biomass of dominant species) - ichthyofauna assemblages dominated by one species (often tolerant fish from Cyprinidae group) are characteristic for highly degraded water environments - thus a high percentage share of biomass of the dominant species is classified as an indicator of bad ecological status of the reservoir.

10. Sub-dominants (number of species with the share $>10 \%$ in the biomass, excluding the dominant species) - existence of several species of moderate, but significant share in fish biomass indicates more 
equal proportions in ichthyofauna assemblage and thus good ecological status of a reservoir.

11. Stocking with piscivore species - permanent, planned human activity which consist of enriching the fish assemblage of the assessed reservoir with species having a positive impact on the ichthyofauna structure and balancing the effects of fishing exploitation constitutes a factor that increases the ecological potential. The amount of stockings $\left(\mathrm{kg} \mathrm{ha}^{-1}\right.$.year $\left.{ }^{-1}\right)$ will be reported on the basis of data received from fishery managers, recalculated for most commonly used stocking material (young of the year), average for the last 5 years before the assessment.

12. Exploitation of piscivore species - since ages fish constitute objects of intensive exploitation by humans and nowadays, with the domination of angling, piscivore species, having a key role in water ecosystems as regulators of tolerant species abundance, are particularly endangered by overfishing (such as pike, pike perch, catfish, asp, lake trout, Danube salmon, eel and perch). Therefore excessive exploitation level of these species is a factor decreasing the ecological potential of waters. The size of catches will be given for all piscivore species together in $\mathrm{kg}$ $\mathrm{ha}^{-1}$.year ${ }^{-1}$ according to data received from fishery managers, average for the last 5 years. Both commercial catches, as well as estimations of anglers' catches will be taken into account.

\section{Model values of assessment parameters for a chosen type of dam reservoirs}

A model table of assessment criteria values (Tab. 3) was elaborated for large, lowland, shallow, lotic reservoirs (type no 4, Tab. 1) - e.g. the Zegrzyński Reservoir. In order to implement the proposed system it is necessary to elaborate similar tables for the remaining types of dam reservoirs, taking into account the knowledge on functioning of such ecosystems and on the composition and structure of ichthyofauna of reservoirs that are assessed by experts to represent good ecological potential. Then, it would be necessary to test the index on a sample of reservoirs of each type, for which detailed data on ichthyofauna composition are available.

The assessment parameters values presented in the table permit to calculate the ecological potential for a reservoir with parameters corresponding to the ranges given to large, lowland, shallow, reolimnic reservoirs, with average depth below $5 \mathrm{~m}$ (e.g. the Zegrze Reservoir). However, in order to assess the ecological potential of other types of reservoirs specified in Table 1, it is necessary to elaborate similar ranges of values for particular assessment parameters.

\section{Principles of data collection on ichthyofauna of dam reservoirs}

In order to obtain reliable data on ichthyofauna of dam reservoirs for the assessment of their ecological potential, according to the criteria listed in Table 2 it is necessary to use combined methods of data collection, such as:

1. Electrofishing (coastal zone). 
TABLE 3. Criteria values for assessment of ecological potential of large, lowland, shallow lotic reservoirs (type no 4, Table 1)

\begin{tabular}{|c|c|c|c|c|}
\hline \multicolumn{2}{|r|}{ Criterion of ecological potential assessment } & \multicolumn{3}{|c|}{$\begin{array}{c}\text { Points (for reservoirs type } 4, \\
\text { Table 2) }\end{array}$} \\
\hline No & Criterion & 5 & 3 & 1 \\
\hline 1 & Total number of species & $>20$ & $15-20$ & $<15$ \\
\hline 2 & Number of intolerant species & $>4$ & $3-4$ & $<3$ \\
\hline 3 & Number of piscivore species & $>4$ & $3-4$ & $<3$ \\
\hline 4 & Number of invertivore species* & $>6$ & $4-6$ & $<4$ \\
\hline 5 & $\begin{array}{l}\text { Number of lithophilic and phytophylic spawning } \\
\text { species }\end{array}$ & $>6$ & $4-6$ & $<4$ \\
\hline 6 & Per cent biomass of piscivore fish & $>25$ & $10-25$ & $<10$ \\
\hline 7 & Per cent biomass of invertivores & $>25$ & $10-25$ & $<10$ \\
\hline 8 & $\begin{array}{l}\text { Per cent biomass of tolerant species (bream, white } \\
\text { bream, roach, silver carp) }\end{array}$ & $<40$ & $40-70$ & $>70$ \\
\hline 9 & Domination ( $\%$ biomass of dominant species) & $<30$ & $30-60$ & $>60$ \\
\hline 10 & $\begin{array}{l}\text { Sub-dominants - number of species with the share } \\
>10 \% \text { in the biomass, excluding the dominant species }\end{array}$ & $>3$ & $2-3$ & $<2$ \\
\hline 11 & Stocking with piscivore species $\left(\mathrm{kg} \cdot \mathrm{ha}^{-1} \cdot \mathrm{year}^{-1}\right)^{*}$ & $>5$ & $2-5$ & $<2$ \\
\hline 12 & Exploitation of piscivore species $\left(\mathrm{kg} \cdot \mathrm{ha}^{-1} \cdot\right.$ year $\left.^{-1}\right)$ & $<4$ & $4-8$ & $>8$ \\
\hline
\end{tabular}

* amount of stocking recalculated for most commonly used stocking material (young of the year).

2. Commercial net catches (if there is commercial fishery in the reservoir).

3. Experimental net catches:

a. In addition (to complement the data on commercial catches) nets with smaller mesh size than in commercial fishery, different fishing grounds,

b. Full range of catches (nets with different mesh sizes, longer period of fishing) - if there is no commercial fishery.

4. Data from fishery managers on stockings and fishing exploitation in the reservoir.

It should be underlined that studies of the ichthyofauna of reservoirs in the monitoring system should be planned taking into account the following amount of work and time:
1. 2-4 weeks for a large or medium-size reservoir (more than $300 \mathrm{ha}$ ) and 2-7 days for a small one (20 to $300 \mathrm{ha}$ );

2. A team of respectively 6 and 4 persons - for a large or medium and small reservoir (net catches and electrofishing);

3. Data collection in a given period of the year - most favourable from midAugust until mid-October, so as to obtain results that are comparable between reservoirs;

4. Repetition of monitoring with the frequency of 5 years for a given reservoir.

The principles of monitoring system presented above guarantee its reliability for the assessment of ecological potential of dam reservoirs on the basis of fish assemblages. 


\section{DISCUSSION}

When selecting the types of waters for monitoring purposes and assessment in accordance with the principles of the WFD, the principle of limiting the number of types, offered by the diversity of the existing water environments, as much as possible should be followed, in order to avoid the implementation of an overly complicated monitoring system. The proposed division does not, of course, exhaust the diversification of the dam reservoirs that exist in Poland. Such elements as size of drainage basin and use of its surface existence or lack of thermal stratification in the summer have been omitted. Differentiation of types according to "ecoregions" remains an open question. In case of Poland such differentiation seems to be less legitimate, especially in the Central and Eastern Plains, that cover an area in the Polish territory with a relatively small geographical and environmental differentiation. Further limitation of the number of types of reservoirs could be taken into account by omitting the quite arbitrary division provided by WFD according to the altitude above sea level. In Poland, reservoirs of very similar character exist both in areas located below or above $200 \mathrm{~m}$ a.s.1., therefore such differentiation does not seem necessary. Thus the number of types cud be reduced from 24 to 12. Instead, a simplified division into "ecoregions" could be applied, taking the Central and Eastern Plains as one class, and the Carpathians Mountains and Central Highlands as another class. Such division would better reflect the environmental differentiation of plain and highland reservoirs and mountain reservoirs than the limit of $200 \mathrm{~m}$ a.s.l., whereas the number of differentiated types would again reach 24. In order to decrease the number of proposed types it is possible to join the size classes of 301-1000 and $>1000$ ha into one class ( $>300 \mathrm{ha})$. This could be justified to a certain degree by a small number of such reservoirs in Poland (both classes in total amount to approximately 30), however such principle would result in classifying very big reservoirs (2-7 thousand ha) and relatively small reservoirs (approximately 300-400 ha) into one type and would therefore significantly decrease the accuracy of the assessments of ecological status done on the basis of uniform criteria.

When elaborating the criteria referring to quantitative proportions of species groups in the ichthyofauna assemblage (Tab. 2), the criterion referring to the percentage of the number of individuals proposed by earlier studies (Karr 1981, McDonough and Hickman 1999, Buras et al. 2004, Szlakowski et al. 2004) has been replaced by the percentage of biomass. This is necessary for the use in an assessment system of the existing data from commercial catches in dam reservoirs (Wiśniewolski 2002).

When elaborating the criteria proposed in Table 3. for large, lowland, lotic reservoirs (such as the Zegrzyński Reservoir) several studies have been taken into account, that contain large knowledge on the functioning of ecosystems of this type of reservoirs (Kajak 1990, Kajak and Prus 2003, Prus and Wiśniewolski 2005) as well as on the structure of ichthyofauna assemblages, fish biomass and fishing exploitation (Wiśniewolski 2002, Szlakowski and 
Wiśniewolski 2001). In case of other types of reservoirs, in particular medium and small, this type of data is more limited and less accessible, and sometimes not existing at all. This is a major obstacle in selecting the assessment parameters for such reservoirs and in some cases may require pilot studies of selected reservoirs.

It should be underlined that the implementation of a monitoring system of dam reservoirs based on ichthyofauna requires the use of combined methods of data collection such as electrofishing, and experimental net catches as well as the use of data from commercial net catches (McDonough and Hickman 1999, Wiśniewolski 2002). Moreover, data collection should be carried out by a team composed of 4-6 persons for 2 days up to 4 weeks (depending on the size of the reservoir) in a given period of the year (August - October), so as to obtain results that are comparable between reservoirs. The monitoring procedure should be repeated every 5 years.

Only a monitoring system of dam reservoirs organised in such a way and adequately financed will ensure fully reliable assessment of their ecological potential basing on the analysis of ichthyofauna assemblages.

\section{REFERENCES}

BRYLIŃSKA M. (red.) 2000: Ryby słodkowodne Polski, Wydawnictwo Naukowe PWN Warszawa, ss. 521.

BURAS P., WIŚNIEWOLSKI W., SZLAKOWSKI J. 2004: Zespoły ryb w systemie Nidy jako kryterium waloryzacji środowiska rzecznego (W: Bliskie naturze kształtowanie dolin rzecznych, red. T.
Hesse, W. Puchalski), Wyd. Politechniki Koszalińskiej, Koszalin: 237-244.

DIRECTIVE 2000/60EC of the European Parliament and the Council of 23 October 2000 establishing a framework for Community action in the field of water policy, Polish translation available at: Department of Water Resources of the Ministry of Environment: www.mos.gov. $\mathrm{pl} / \mathrm{dzw}$.

Improvement and spatial Extension of the European Fish Index (EFI+). 2009 (http:// efi-plus.boku.ac.at/)

KAJAK Z. (red.) 1990: Funkcjonowanie ekosystemów wodnych, ich ochrona i rekultywacja. Część I. Ekologia zbiorników zaporowych i rzek. Wyd. SGGW-AR, Warszawa, ss. 340.

KAJAK Z., PRUS P. 2003: Seasonal and year-to-year variation of numbers of Chironomus plumosus L. and Tubificidae in a lowland reservoir: regularities, causes, mechanisms, Polish Journal of Ecology, 51: 339-351.

KARR J.R. 1981: Assessment of biotic integrity using fish communities, Fisheries, 6: 21-27.

McDONOUGH T.A., HICKMAN G.D. 1999: Reservoir fish assemblage index development: A tool for assessing ecological health in Tennessee Valley Authority Impoundments (In: Assessing the sustainability and biological integrity of water resources using fish communities, Ed. T.P. Simon), CRC Press, Boca Raton, New York, Washington, D.C.: 523-540.

MASTYŃSKI J., 1985: Gospodarka rybacka i możliwości produkcyjne wybranych zbiorników zaporowych Polski-Roczniki Akademii Rolniczej w Poznaniu, 146: 5-90.

PRUS P., WIŚNIEWOLSKI W. 2005: Zróżnicowanie bazy pokarmowej ryb w górskim i nizinnym zbiorniku zaporowym i jego konsekwencje dla składu ichtiofauny. (W: Rybactwo w jeziorach, rzekach i zbiornikach zaporowych w 2004 roku), Wyd. IRŚ, Olsztyn, 2005: 87-106. 
SCHMUTZ S., COWX I.G., HEIDVOGL G., PONT D. 2007: Fish-based methods for assessing European running waters; a synthesis. Fisheries Management and Ecology 14 (6): 369-380.

STARMACH K, WRÓBEL S., PASTERNAK K. 1976: Hydrobiologia, PWN, Warszawa, ss. 621.

SZLAKOWSKI J., BURAS P., WIŚNIEWOLSKI W. 2004: Wskaźnik integralności biotycznej (IBI) jako narzędzie do waloryzacji rzek w oparciu o zespoły ichtiofauny (W: Bliskie naturze ksztattowanie dolin rzecznych, Red. T. Hesse, W Puchalski), Wyd. Politechniki Koszalińskiej, Koszalin: 245-262.

SZLAKOWSKI J., WIŚNIEWOLSKI W. 2001: Biomasa ryb Zbiornika Zegrzyńskiego w aspekcie ich eksploatacji na przykładzie krapia, Blicca bjoerkna (Linnaeus, 1758). Supplementa ad Acta Hydrobiologica, 1: 67-76, Kraków.

WIŚNIEWOLSKI W. 2002: Zmiany w składzie ichtiofauny, jej biomasa oraz odłowy w wybranych zbiornikach zaporowych Polski, Arch. Pol. Fish., Vol. 10, Suppl. 2: 5-73.

Streszczenie: Wstępe założenia indeksu oceny stanu zbiorników zaporowych na podstawie zespołów ichtiofauny. Ramowa Dyrektywa Wodna (Dyrektywa 2000/60/WE Parlamentu Europejskiego i Rady z dnia 23 października 2000 r.) ustanawiająca zasady wspólnotowego działania w dziedzinie polityki wodnej, nakłada na państwa członkowskie nie tylko obowiązek monitorowania i poprawy stanu ekologicznego wód naturalnych, ale też określenia potencjału ekologicznego sztucznych i silnie zmienionych czesści wód. Na podstawie kryteriów geograficznych, fizycznych oraz hydrologicznych proponuje się wyróżnienie dla Polski 24 typów zbiorników zaporowych. System oceny potencjału ekologicznego oparto na schemacie wskaźnika integralności biotycznej (IBI), z uwzględnieniem modyfikacji przeprowadzonych dla rzek Polski. Opracowano przykładową tabelę wartości kryteriów oceny dla dużych, nizinnych, płytkich zbiorników przepływowych. Dla wdrożenia proponowanego systemu oceny niezbędne jest wykonanie analogicznych tabel dla pozostałych typów zbiorników zaporowych, a następnie przetestowanie działania wskaźnika na próbie zbiorników różnych typów. Należy podkreślić, że dla uzyskania miarodajnych danych dotyczących ichtiofauny zbiorników zaporowych, do przeprowadzenia oceny ich stanu ekologicznego konieczne jest stosowanie kombinowanych metod zbioru materiałów (elektropołowy, eksperymentalne i gospodarcze odłowy sieciowe) w planowanym systemie monitoringu.

MS. received November 2009

\section{Authors' address:}

Wiesław Wiśniewolski

Instytut Rybactwa Śródlądowego

ul. Główna 48, Żabieniec,

05-500 Piaseczno

Poland,

e-mail: rzeki@infish.com.pl 